\title{
Seed contamination in sheep: new investigations into an old problem
}

by Kelly, J.E., Quinn, J.C., Loukopoulos, P., Broster, J.C., Behrendt, K. and Weston, L.A.

Copyright, Publisher and Additional Information: This is the author accepted manuscript. The final published version (version of record) is available online via CSIRO Publishing.

Please refer to any applicable terms of use of the publisher.

DOI: https://doi.org/10.1071/AN17771

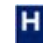

Harper Adams University

Kelly, J.E., Quinn, J.C., Loukopoulos, P., Broster, J.C., Behrendt, K. and Weston, L.A. 2018. Seed contamination in sheep: new investigations into an old problem. Animal Production Science. 


\section{iㅔ ANIMAL PRODUCTION SCIENCE}

\section{Seed contamination in sheep: new investigations into an old problem}

\begin{tabular}{|c|c|}
\hline Journal: & Animal Production Science \\
\hline Manuscript ID & AN17771.R2 \\
\hline Manuscript Type: & Research paper \\
\hline Date Submitted by the Author: & 27-Feb-2018 \\
\hline Complete List of Authors: & $\begin{array}{l}\text { Kelly, Jane; Charles Sturt University - Wagga Wagga Campus, Animal and } \\
\text { Veterinary Sciences; The Graham Centre for Agricultural Innovation, } \\
\text { Charles Sturt University and New South Wales Department of Primary } \\
\text { Industries } \\
\text { Quinn, Jane; Charles Sturt University - Wagga Wagga Campus, Animal and } \\
\text { Veterinary Sciences; The Graham Centre for Agricultural Innovation, } \\
\text { Charles Sturt University and New South Wales Department of Primary } \\
\text { Industries } \\
\text { Loukopoulos, Panayiotis; Charles Sturt University - Wagga Wagga Campus, } \\
\text { Animal and Veterinary Sciences; The Graham Centre for Agricultural } \\
\text { Innovation, Charles Sturt University and New South Wales Department of } \\
\text { Primary Industries } \\
\text { Broster, John; Charles Sturt University, School of Agricultural and Wine } \\
\text { Sciences } \\
\text { Behrendt, Karl; Harper Adams University College } \\
\text { Weston, Leslie; The Graham Centre for Agricultural Innovation, Charles } \\
\text { Sturt University and New South Wales Department of Primary Industries }\end{array}$ \\
\hline Keyword: & Sheep meat, Sheep pelts, Carcass, Meat processing, Grasses \\
\hline
\end{tabular}




\section{Seed contamination in sheep: new investigations into an old problem}

2 J.E. Kelly ${ }^{A, B^{*}}$ J.C. Quinn ${ }^{A, B}$, P. Loukopoulos ${ }^{A, B}$, J.C. Broster ${ }^{A, B}$, K. Behrendt ${ }^{A, B, C}$ and L.

3 A. Weston ${ }^{\text {B }}$

4

$5 \quad{ }^{A}$ Charles Sturt University, Locked Bag 588, Wagga Wagga, New South Wales 2678, Australia

$6{ }^{\mathrm{B}}$ Graham Centre for Agricultural Innovation, Charles Sturt University, Locked Bag 588,

7 Wagga Wagga, New South Wales 2678, Australia

$8{ }^{\mathrm{C}}$ Harper Adams University, Newport, Shropshire, TF10 8NB, United Kingdom

11 *Corresponding author. School of Agricultural and Wine Sciences, Charles Sturt University, PO Box 883,

12 Orange, NSW, Australia. Tel.:+61 0263656576 E-mail address: janekelly@csu.edu.au

14 Short title: Seed contamination in sheep: new investigations

15 Word count: 5108 (count includes abstract, article body, references, acknowledgements and figure caption list)

Summary text for table of contents

17 Seed contamination of sheep fleece and carcasses causes significant production losses. Recent studies indicate distribution and frequency of carcass damage across Australia are associated with the distribution of barley and brome grass populations, and varies with state, region, year, animal and climate factors. Reviewing the literature on this issue highlights areas requiring future research, including the investigation of effective weed management strategies for current Australian conditions. 
26 Abstract. Seed contamination significantly impacts production capacity and animal welfare in Australian sheep

27 flocks and causes considerable financial loss to producers and processors across sheepmeat value chains. Seven

28 grass weed species contribute to seed carcass contamination in Australia, with barley grass (Hordeum spp.) identified as a key perpetrator. Herbicide resistance and variable dormancy emerging in southern Australian barley grass populations are thought to enhance its capacity for successful pasture invasion, further exacerbating the potential for seed contamination in sheep. This article reviews the current literature regarding the impact and incidence of seed contamination on sheepmeat production, with particular reference to key grass weed species prevalence across Australia. Data is presented on recent incidence of carcass contamination across years, where incidence varied between 11 and 80\% from 2009 to 2013, contracting to between 2 and $60 \%$ during 2014 and 2015. Key areas requiring future research are defined. Understanding the biology of key grass weeds, historical influences and economic consequences associated with seed contamination in sheep may assist in defining future risks to sheep production and improve weed management. Furthermore, examining more recent data describing the current status of seed contamination across Australia and associations with causal weed species may aid the development of critical weed management strategies in highly infested regions, subsequently limiting the extent of future seed contamination.

\section{Additional keywords: Sheepmeat, Sheep pelts, Carcass, Meat processing, Grasses}

\section{Introduction}

43 Seed contamination in sheep refers to the penetration of body tissues by the seeds of certain grass weeds 44 during grazing, which is an increasing problem within the Australian sheep industry. Affected sheep suffer considerable physical injury, including penetration of external tissues, carcass and internal organs. 1974; Collins et al. 2013; Smith 2014). Affected sheep exhibit reduced growth rates, considerable weight loss and mortality (Dodd 1919; Atkinson and Hartley 1972; Hartley and Bimler 1975) and contamination of wool results in price discounts due to extra wool processing costs (Lunney 1983; Nolan et al. 2014).

50 Of the seven annual grass weed species known to contribute to seed contamination (Collins et al. 2013), barley grass (Hordeum spp. Link.) and brome grass (Bromus spp. Roth.) are frequently associated with carcass damage

52 (Atkinson and Hartley 1972; Tozer et al. 2008). Furthermore, recent evidence suggests invasion capability has

53 increased in barley grass and brome grass populations, a result of growing herbicide resistance and variable 
54

dormancy patterns in many Australian populations (Gill and Blacklow 1985; Fleet and Gill 2012; Boutsalis et al. 2014; Owen et al. 2015; Shergill et al. 2015b; Shergill et al. 2017a; Shergill et al. 2017b). These factors present challenges for effective management of both species, and lack of control may result in increased incidence of carcass damage.

This review examines historical and recent literature regarding factors influencing seed contamination and impacts upon sheepmeat production, so as to assist in identifying future research needs and / or mitigation strategies to reduce invasive grass infestation and carcass contamination.

\section{Seed contamination in sheep}

Seed contamination of sheep commonly occurs as a consequence of management or seasonal influences (Collins et al. 2013; George 1972; Kelly et al. 2016, Kelly 2016). When seeds dislodge from the plant's inflorescence due to disturbance by grazing, seed awns adhere to the fleece and animal movement aids seed transport to the skin, resulting in body tissue penetration (Fig.1). Grass seed dispersal often corresponds with highest rates of seed contamination (Warr 1980), which causes significant injury (Dodd 1919; Mulham and Moore 1970; Hartley and Atkinson 1972; Hartley and Bimler 1975; Little et al. 1992). The issue presents many welfare and production challenges which are not often realised until slaughter when carcass damage becomes visible.

\section{Insert Fig 1 here}

\section{Problematic weed species contributing to seed contamination}

The introduced and widely distributed weed, barley grass (Hordeum spp. Link.), has been historically problematic in contributing to seed contamination (Dodd 1919). Also implicated were the native grasses; spear grass (Austrostipa spp (Lindley) S.W.L. Jacobs and Everett), wire grass (Aristida spp. R. Br.) and silver grass (Vulpia bromoides (L). Gray) (Dodd 1919). Despite almost 100 years of research, all of these species continue to cause carcass damage (Collins 2013). While Storksbill (Erodium spp. (L.) L'Hér), Chilean needle grass (Nasella neesiana (Trin. \& Rupr.)) and brome grass infestations (Bromus spp. Roth) also result in seed contamination, the following species; Hordeum spp., Vulpia spp., Stipa spp., and Erodium spp. are considered by sheepmeat processors as the major carcass contaminants in Australia (Collins 2013). 
Brome grass and barley grass are currently listed within the top twenty residual weeds of southern Australian grain growing regions (Llewellyn et al. 2016). Interestingly, certain populations of these grasses are spreading due to herbicide resistance (Owen et al. 2015; Shergill et al. 2015a, 2016b; Shergill et al. 2017a; Shergill et al. 2017b) and variable seed dormancy patterns (Fleet and Gill 2012; Kleemann and Gill 2013) as a result of repeated herbicide exposure, changing farming practices (Fleet and Gill 2012; Recasens et al. 2016) and potential adaptation to variable climatic conditions (Smith 1968; Gill and Blacklow 1985). Brome grass and barley grass now inhabits over 1.4 million hectares and 244,000 hectares, respectively (Llewellyn et al. 2016).

Three barley grass subspecies are commonly found in Australia. They are collectively referred to as the Hordeum murinum complex (Cocks et al. 1976) comprised of H. leporinum Link. H. glaucum Steud. and $H$. murinum L. (Cocks et al. 1976). A less common fourth subspecies, H. hystrix Roth., is also noted within Australian National Herbarium collections (D Albrecht, pers. comm.).

\section{Distribution of problematic weed species}

Hordeum spp. (and Vulpia spp) are among the five most prevalent pasture weeds across the New South Wales perennial pasture zone (Dellow et al. 2002). Together with Bromus spp., they are common to southern New South Wales cropping regions (Lemerle et al. 1996; Broster et al. 2012b). Bromus rigidus frequently invades cropping fields, while B. diandrus, another injurious Bromus species, often occupies roadsides and disturbed areas (Kleemann and Gill 2006). Hordeum glaucum invades drier, semi-arid regions ( $<425 \mathrm{~mm}$ annual rainfall), Hordeum leporinum commonly occupies regions above $425 \mathrm{~mm}$ annual rainfall and Hordeum murinum most frequently inhabits Tasmania (Cocks et al. 1976). In Western Australia, both Hordeum spp. and Bromus spp. have colonised up to $64 \%$ of cropping fields (Borger et al. 2012), with 1-3\% invading summer fallows (Michael et al. 2010). However, in northern NSW and Queensland Hordeum spp. are scarce, occurring in less than $1 \%$ of arable fields (Osten et al. 2007). Together, both species are noted at a frequency of less than $10 \%$ in Tasmania (Broster et al. 2012a).

\section{Production loss, morbidity and animal welfare concerns associated with seed contamination}

Previous reports highlight reduced growth rates and live weight losses of up to $11.5 \mathrm{~kg}$ per head within three months in contaminated sheep (Mulham and Moore 1970; Campbell et al. 1972; Hartley and Atkinson 1972, 1973a; Hartley and Bimler 1975; Hartley 1976; Hamilton 1978; Little et al. 1992). Significant weight loss leads to reduced reproductive capacity in adults and restricts progeny growth (Behrendt et al. 2011). Seeds penetrate 
eyes causing inflammation (Dodd 1919; George 1972), blindness (Hartley and Atkinson 1972), facial injuries (George 1972; Hartley and Bimler 1975; Hartley 1976), skin abscesses and ulcerations (Dodd 1919; Belschner 1925; Loughnan 1964; Barry 1971). Seeds penetrating internal organs may also cause peritonitis, pleurisy (Dodd 1919; Loughnan 1964) and tetanus (Belschner 1925), while lameness occurs from seed penetration of the feet. Generalised inflammation and fever commonly occurs from seed wound infections and mortality rates are often significant (Mulham and Moore 1970; Cornish and Beale 1974; Hartley and Bimler 1975). Seed contamination also impacts animal welfare, where sheep may experience increased flystrike susceptibility and significant physical discomfort associated with seed injury (Dodd 1919; Loughnan 1964; Campbell et al. 1972).

\section{Animal factors leading to seed contamination}

Numerous physiological factors appear to influence seed contamination in sheep. Young animals and sheep with heavily wrinkled skin are predisposed to heavy contamination compared to older sheep or those carrying less skin wrinkle (Dodd 1919; Mulham and Moore 1970; Campbell et al. 1972; Shugg and Vivian 1973; Cornish and Beale 1974; Hartley and Bimler 1975). Studies also highlight the predisposition of Merino wool to seed attachment compared to Romney and Border Leicester wool types (Atkinson and Hartley 1972; Hartley and Atkinson 1973b; Shugg and Vivian 1973; Hartley and Bimler 1975; Hartley 1976), although seed attachment was not necessarily associated with fibre diameter (Hartley and Atkinson 1973b). Skins with longer wool commonly attract higher seed burdens in contrast to skins with shorter wool (Mulham and Moore 1970; Hartley and Atkinson 1973b; Shugg and Vivian 1973; Cornish and Beale 1974; Little et al. 1992; Mason et al. 2008; Mason and Behrendt 2009). Despite this, skins with longer wool generally attract higher prices due to the value placed on these skins in some markets (Mason et al. 2008).

\section{Economic impacts of seed contamination in sheep}

The economic impacts of seed contamination on farm have not been fully evaluated in Australia. Previous literature describes significant carcass, skin and wool price discounts incurred by producers as a result of seed contamination (Cornish and Beale 1974; Sloane et al. 1989; Collins 2013). Discounts between $\$ 0.10$ to $\$ 1 / \mathrm{kg}$ carcass weight are commonly applied within abattoirs (Collins 2013), reducing carcass value per animal by up to $\$ 6$ per head (Little et al. 1992). In addition, costs associated with live weight loss on meat yield, fertility and wool production (Killeen 1976; Kellaway 1973), morbidity (Dodd 1919; Holmes 1993) and mortality (Dodd 1919; Campbell et al. 1972; George 1972) are also significant. Secondary costs include those associated with 
altered management to accommodate contaminated animals (Collins et al. 2013), herbicide application for weed control (Sloane et al. 1989) and reduced pasture availability for live weight gain after herbicide application (Hartley et al. 1974).

\section{Impact of seed contamination upon the sheepmeat processing sector}

Seed contamination is a key factor affecting abattoir profitability (Collins 2013), where incidence tends to be variable across years and is subject to seasonal influences upon seed production (Cornish and Beale 1974; Collins 2013). Seed contamination leads to carcass rejection by export markets, downgrading of meat products and the potential for loss of export licenses (Loughnan 1964; Shugg and Vivian 1973; Cornish and Beale 1974; Smith 2014). Sheepmeat markets require total seed removal from contaminated carcasses, reducing carcass weight by up to $4-5 \mathrm{~kg}$ and reducing meat yield as a consequence of excessive trimming (Loughnan 1964; Shugg and Vivian 1973). Additional trimming reduces throughput from slower chain speeds and increases labour costs by $60 \%$ (Collins 2013; Collins et al. 2013; Smith 2014). Although one sheepmeat processor reported an annual cost of $\$ 3$ million to their business due to seed contamination (Collins 2013), many processors have estimated the cost to be $\$ 20-30$ per carcass (Collins 2013). Seed contamination also affects pelt quality (Loughnan 1964; Mulham and Moore 1970; Rumball 1970; Atkinson and Hartley 1972) and value (Atkinson and Hartley 1972), which reduces market options (Collins et al. 2013).

\section{Current trends in carcass seed contamination in Australia}

\section{Regional prevalence of seed contamination and associations with distribution of key grass weeds}

Recent studies performed by the authors have utilised a national database (curated by Animal Health Australia) to explore the current factors affecting incidence and distribution of seed contamination in sheep carcasses across Australia. Analysis results revealed variable incidence across states and regions, with contamination noted most frequently across mainland states in contrast to Tasmania (Kelly et al. 2016; Kelly 2016). Contamination was associated with barley and brome grass distribution across the mixed farming and pastoral zones, a logical result given the presence of large adjoining sheep and cropping enterprises and the prevalence of both weed species across southern cropping regions (Llewellyn et al. 2016). Significant contamination of sheep in the high rainfall zone was also noted, suggesting the distribution of other key grass weeds producing penetrating seeds within this biogeographic zone. Also identified were significant effects of sheep sex and age on incidence of contamination (Kelly et al. 2016; Kelly 2016). Higher frequencies of 
164

165

166

167

168

169

170

171

172

173

174

175

176

177

178

179

180

181

182

183

184

185

186

187

188

189

190

191

contamination were noted in both sexes over two years of age and entire males sold for slaughter (cast for age rams) in contrast to younger sheep of either sex, likely due to the repeated exposure to seed in older animals as a result of the length of time on farm in contaminated paddocks. Incidence of seed contamination was also significantly influenced by both climatic factors and altitude, likely reflective of the variable ecological requirements of weeds associated with contamination and the seasonal variation in seed production and contamination (Kelly 2016).

Impact of year on the regional incidence of seed contamination

The results of this study also revealed significant differences in contamination across years throughout Queensland, New South Wales, Victoria and South Australian regions between 2009 and $2015(P<0.001$, Fig. 2).

Insert Figure 2 here

Carcass contamination frequency across all states ranged between 11 and 80\% between 2009 and 2013 and contracted during 2014 and 2015, to between 2 and 60\%. The array of regions exhibiting contamination also generally increased from 2013 to 2015, likely a reflection of season and flock management (Collins 2013; George 1972). In 2009, the combination of significant rainfall events and warmer conditions signifying the end of the millennium drought (Bureau of Meteorology 2009, 2011, 2012) likely created conditions favourable for annual weed competition and proliferation (Kelly et al. 2016), leading to increased physical contact with sheep grazing these regions. Wetter seasonal conditions also led to increased sheep and lamb numbers (Caboche and Thompson, 2013) and reduced sheep slaughter numbers, leading to high retention of sheep on farm during 2010 and 2011 (Thomas and Matthews 2016), where exposure to ample seed produced by thriving weed populations was likely. This may explain the higher contamination frequency in certain regions during 2012, where slaughter of animals (likely contaminated with seed from the previous years), had increased due to dry conditions prevailing in the latter half of the year (Bureau of Meteorology 2012; Caboche and Thompson, 2013; Thomas and Matthews 2016;). The broader pattern of contamination observed between 2013 and 2014 possibly reflects the slaughter of previously contaminated sheep sourced from numerous regions with high weed infestation rates. During 2015, the reduced contamination across numerous states and regions may reflect higher lamb slaughter occurring earlier, due to seasonally dry conditions (Ashton et al., 2016), thereby reducing lamb exposure to seed. Given previous findings noting high frequencies of contamination in older sheep, reduced 
Seed contamination in sheep: new investigations

192

193

194

195

196

197

198

199

200

201

202

203

204

205

206

207

208

209

210

211

212

213

214

215

216

217

218

adult sheep slaughter during 2015 may also have contributed to lower contamination incidence during that year as a consequence of adults being retained on farm for flock re-building (Berry, 2015; Thomas and Matthews 2016).

\section{Implications and future research directions}

Climate variability, conservation tillage, and reliance on herbicides for weed management are factors likely to favour the spread of annual grass weeds across southern Australia, thus enabling selection for highly competitive biotypes. The increasing prevalence of seed dormancy and herbicide resistance occurring concurrently within grass weed populations will present additional challenges due to the lack of efficacious herbicide options (Shergill et al. 2015a). As sheep numbers increase across cereal cropping and pasture zones of Australia, these regions face increased rates of future carcass damage, potentially presenting risks for maintaining market access for quality sheepmeat products.

With the Australian sheep industry experiencing a re-building phase, older animals may be retained for longer periods. Creating safe paddocks for housing older animals will be important, as these animals potentially contribute to the spread of weed populations and high levels of carcass damage observed in Australian abattoirs. The procedural differences in data reporting between abattoirs highlights the importance of standardising data collection protocols during processing for more comprehensive monitoring of carcass damage.

Reducing the problem of seed contamination over the longer term will be achieved by effective and proactive control of causative weeds on farm and encouraging the establishment and productivity of competitive pasture species. It is increasingly important to ensure research and outreach efforts address early season weed management before seed set, with particular emphasis in heavily infested regions.

Given the increasing spread of barley grass across southern Australia and its dominant role in sheep carcass damage, cost effective cultural and chemical management strategies should target Hordeum spp. Currently, species distribution across Australia is unknown and complicated by misidentification (Cocks et al. 1976). Therefore, accurate subspecies identification across all biogeographic regions would be valuable to develop species-specific control strategies for Hordeum spp. Given the frequency of barley grass infestations within legume pastures used for sheepmeat production, future research regarding the development of integrated control strategies and the identification of chemically diverse herbicides for barley grass control is needed within typical 


\section{Acknowledgements}

We acknowledge the support of the AW Howard Memorial Trust, Meat and Livestock Australia (Project

for Agricultural Innovation (Charles Sturt University and NSW Department of Primary Industries). We are also University for the production of maps. No conflicts of interest have been declared.

Ashton, D, Oliver, M, van Dijk, J, Weragoda, A, Levantis, C (2016) Australian lamb: financial performance of lamb producers, 2013-14 to 2015-16, ABARES research report 16.9, Canberra, September. CC BY 3.0. [Online] Available at https://www.mla.com.au/globalassets/mla-corporate/prices-markets/documents/trends--analysis/abares-farm-survey/abares-financial-performance-slaughter-lamb2013-14-to-2015-16.pdf (accessed 1 February 2018).

Atkinson, G, Hartley, M (1972) Damage caused to lambs by barley grass. In 'Proceedings of the NZ Weed and Pest Control Conference 25'. (Ed. M Hartley) pp. 29-33. (The New Zealand Plant Protection Society Inc.: Christchurch, New Zealand)

Barry, MR (1971) Changes in animal disease patterns in the Riverina of New South Wales. Australian Veterinary Journal 47, 220-225.

Behrendt, R, Van Burgel, A, Bailey, A, Barber, P, Curnow, M, Gordon, D, Hocking Edwards, J, Oldham, C, Thompson, A (2011) On-farm paddock-scale comparisons across southern Australia confirm that 
increasing the nutrition of Merino ewes improves their production and the lifetime performance of their progeny. Animal Production Science 51, 805-812.

Berry, P (2015) Sheepmeat and wool: Outlook to 2019-20 [Online]. Agricultural commodities 5, 112-123. Available at https://search.informit.com.au/fullText;dn=537882111726190;res=IELBUS (accessed 1 February 2018).

Belschner, HG (1925) Mortality amongst sheep due to tetanus following severe infestation with grass seed and subsequent dipping. Australian Veterinary Journal 1, 108-110.

Borger, CPD, Michael, PJ, Mandel, R, Hashem, A, Bowran, D, Renton, M (2012) Linking field and farmer surveys to determine the most important changes to weed incidence. Weed research 52, 564-574.

Boutsalis, P, Kleemann, S, Gill, GS, Preston, C (2014) A hidden threat: widespread Group B herbicide resistance in brome across south-eastern Australia. In 'Proceedings of the 19th Australasian Weeds Conference-Science, Community and Food Security: the Weed Challenge'. (Ed M Baker) pp. 202-205. (Tasmanian Weed Society.: Hobart, Tasmania)

Broster, J, Koetz, E, Wu, H (2012a) Herbicide resistance frequencies in ryegrass ('Lolium'spp.) and other grass species in Tasmania. Plant Protection Quarterly 27, 36.

Broster, J, Koetz, E, Wu, H (2012b) Weed species present in cereal crops in southern New South Wales. In 'Proceedings of the 18th Australasian Weeds Conference-Developing Solutions to Evolving Weed Problems'. (Ed V Eldershaw) pp. 241-244. (Weed Society of Victoria Inc.: Melbourne, Victoria)

Bureau of Meteorology (2009) 'Annual Climate Summary 2009.' [Online] Available at http://www.bom.gov.au/climate/annual_sum/2009/AnClimSum09_LR1.1.pdf (accessed 27th October).

Bureau of Meteorology (2011) 'Annual Climate Summary 2011.' [Online] Available at http://www.bom.gov.au/climate/annual_sum/2011/AnClimSum2011_LR1.0.pdf (accessed 27th October).

Bureau of Meteorology (2012) 'Annual Climate Summary 2012.' [Online] Available at http://www.bom.gov.au/climate/annual_sum/2011/AnClimSum2011_LR1.0.pdf (accessed 27th October).

Caboche, T, Thompson, T (2013) Australian lamb:financial perfromance of slaughter lamb producing farms, 2010-2011 to 2012-2013, ABARES research report 13.7, Canberra, June. CC BY 3.0 [Online] Available at https://www.mla.com.au/globalassets/mla-corporate/prices--markets/documents/trends-- 
analysis/abares-farm-survey/financial-performance-of-slaughter-lamb-producing-farms-2010-11-to2012-13.pdf (accessed 1 February 2018).

Campbell, R, Robards, G, Saville, D (1972) The effect of grass seed on sheep production. Proceedings of the Australian Society of Animal Production 9, 225-229.

Cocks, P, Boyce, K, Kloot, P (1976) The Hordeum murinum Complex in Australia. Australian Journal of Botany 24, 651-662.

Collins, A (2013) Winning Against Seeds: Resources Review and Update, August 2013. Meat and Livestock Australia Ltd, North Sydney, NSW.

Collins, A, Fitzsummons, P, Behrendt, K, Camac, M, McCormick, L, Latta, R, John, C, Sheehan, M, Prance, T, Humphries, A, Hooke, T, McEachern, S, Jolly, S, Dickson, H, Shands, C, James, R, Evans, N (2013) 'Winning against seeds: Management tools for your sheep enterprise.' (Meat and Livestock Australia Ltd: Australia)

Cornish, PS, Beale, JA (1974) Vegetable Fault and Grass Seed Infestation of Sheep in New South Wales. Journal of the Australian Institute of Agricultural Science 40, 261-267.

Dellow, J, Wilson, G, King, WM, Auld, B (2002) Occurrence of weeds in the perennial pasture zone of New South Wales. Plant Protection Quarterly 17, 12-16.

Dodd, S (1919) Infestation of the Skin, Etc., of Sheep by Grass Seeds. Journal of Comparative Pathology and Therapeutics 32, 90-95.

Fleet, B, Gill, G (2012) Seed Dormancy and Seedling Recruitment in Smooth Barley (Hordeum murinum ssp. glaucum) Populations in Southern Australia. Weed Science 60, 394-400.

George, J (1972) Effects of grazing by sheep on barley grass (Hordeum leporinum Link) infestation of pastures. Proceedings of the Australian Society of Animal Production 9, 221-224.

Gill, G, Blacklow, W (1985) Variations in seed dormancy and rates of development of great brome, Bromus diandrus Roth., as adaptations to the climates of southern Australia and implications for weed control. Australian Journal of Agricultural Research 36, 295-304.

Hamilton, BA (1978) Grass seed contamination of sheep carcasses. Wool technology and sheep breeding 26, 1517.

Hartley, M (1976) Some effects of barley grass seed on young sheep. In 'Proceedings of the New Zealand Grassland Association Volume 37’.pp. 59-65. (New Zealand Grasslands Association, Hastings, New Zealand). 
Seed contamination in sheep: new investigations

Hartley, M, Atkinson, G (1972) Effect of chemical removal of barley grass on lamb growth rates. In 'Proceedings of the NZ Weed and Pest Control Conference 25'. (Ed. M Hartley) pp. 23-28. (The New Zealand Plant Protection Society Inc.: Christchurch, New Zealand)

Hartley, M, Atkinson, G (1973a) Effect of chemical removal of barley grass on lamb growth rates: Part II. In 'Proceedings of the NZ Weed and Pest Control Conference 26'. (Ed. M Hartley) pp. 92-97. (The New Zealand Plant Protection Society Inc.: Auckland, New Zealand)

Hartley, M, Atkinson, G (1973b) Effect of wool type on barley grass damage to lambs. In 'Proceedings of the NZ Weed and Pest Control Conference 26'. (Ed. M Hartley) pp. 87-91. (The New Zealand Plant Protection Society Inc.: Auckland, New Zealand)

Hartley, M, Atkinson, G, Bimbler, K, Douch, G (1974) Chemical control of barley grass under grazing conditions. In 'Proceedings of the NZ Weed and Pest Control Conference 27'. (Ed. M Hartley) pp. 7478. (The New Zealand Plant Protection Society Inc.: Nelson, New Zealand)

Hartley, M, Bimler, K (1975) Barley grass damage to lambs. In 'Proceedings of the NZ Weed and Pest Control Conference 28'. (Ed. M Hartley) pp. 2-6. (The New Zealand Plant Protection Society Inc.: Hastings, New Zealand)

Holmes, PH (1993) Interactions between parasites and animal nutrition: the veterinary consequences. Proceedings of the Nutrition Society 52, 113-120.

Kellaway, R (1973) The effects of plane of nutrition, genotype and sex on growth, body composition and wool production in grazing sheep. The Journal of Agricultural Science 80, 17-27.

Kelly, JE (2016) Defining cause and effects associated with prevalence of key weeds across the region in terms of livestock productivity and carcass quality. Report for MLA project B.WEE.0146, August 2016 (Charles Sturt University: NSW)

Kelly, JE, Quinn, JC, Loukopoulos, P, Nielsen, SG, Weston, P, Broster, JC, Weston, LA (2016) Current perspectives on the impact of weed seed contamination in sheep. In 'Proceedings of the 20th Australasian Weeds Conference'. (Eds R Randall, S Lloyd, C Borger) pp. 11-15. (Weeds Society of Western Australia, Perth, Western Australia)

Killeen, I (1967) The effects of body weight and level of nutrition before, during, and after joining on ewe fertility. Animal Production Science 7, 126-136. 
Kleemann, SGL, Gill, GS (2006) Differences in the distribution and seed germination behaviour of populations of Bromus rigidus and Bromus diandrus in South Australia: adaptations to habitat and implications for weed management. Australian Journal of Agricultural Research 57, 213-219.

Kleemann, SGL, Gill, GS (2013) Seed dormancy and seedling emergence in ripgut brome (Bromus diandrus) populations in southern Australia. Weed Science 61, 222-229.

Lemerle, D, Tang, H, Murray, G, Morris, S (1996) Survey of weeds and diseases in cereal crops in the southern wheat belt of New South Wales. Australian Journal of Experimental Agriculture 36, 545-554.

Little, DI, Carter, ED, Ewers, AI (1992) The impact of grass control on Merino lamb production in the cereal belt of south Australia. In 'Proceedings of the 6th Australian Agronomy Conference'. (Eds KJ Hutchinson and PJ Vickery) (The Australian Agronomy Society Inc.: Melbourne)

Llewellyn, R, Ronning, M, Ouzman, J, Walker, S, Mayfield, A, Clarke, M (2016) Impact of Weeds on Australian Grain Production: The cost of weeds to Australian grain growers and the adoption of weed management and tillage practices. (CSIRO: Australia).

Lodge, G, Hamilton, B (1981) Grass seed contamination of the wool and carcases of sheep grazing natural pasture on the north-western slopes of New South Wales. Australian Journal of Experimental Agriculture 21, 382-386.

Loughnan, RJM (1964) Economic losses from barley grass. In 'Proceedings of the NZ Weed and Pest Control Conference 17'. (Ed. LJ Matthews) pp. 21-23 (The New Zealand Weed and Pest Control Conference Inc.: Nelson, New Zealand)

Lunney, H (1983) Vegetable fault in Australian wool: classification, consequences, and economic loss. Journal of the Australian Institute of Agricultural Science 49, 207-211.

Mason, J, Behrendt, K (2009) Producers dealing with problem pasture species that cause seed contamination and production losses in lamb production systems. In 'Proceedings of the 24th Annual Conference of the Grasslands Society of NSW’ (Eds D Brouwer, N Griffiths, I Blackwood) pp.5-6. (Grasslands Society of NSW: Orange, NSW)

Mason, J, Behrendt, K, Toohey, E, White, A (2008) Using Bioclip ${ }^{\mathrm{TM}}$ to Manage the Impact of Grass Seed Contamination on Lamb Production. In 'Coping with a changing environment: environmental, technological, social and economic'. pp. 237-238. (NSW Department of Primary Industries: Orange, NSW) 
Seed contamination in sheep: new investigations

Michael, PJ, Borger, CP, MacLeod, WJ, Payne, PL (2010) Occurrence of Summer Fallow Weeds within the Grain Belt Region of Southwestern Australia. Weed Technology 24, 562-568.

Mulham, W, Moore, C (1970) The grass seed problem. Pastoral Review 80, 105.

Nolan, E, Farrell, T, Ryan, M, Gibbon, C, Ahmadi-Esfahani, FZ (2014) Valuing quality attributes of Australian Merino wool. Australian Journal of Agricultural and Resource Economics 58, 314-335.

Osten, VA, Walker, SR, Storrie, A, Widderick, M, Moylan, P, Robinson, GR, Galea, K (2007) Survey of weed flora and management relative to cropping practices in the north-eastern grain region of Australia. Australian Journal of Experimental Agriculture 47, 57-70.

Owen, M, Goggin, D, Powles, S (2012) Identification of resistance to either paraquat or ALS-inhibiting herbicides in two Western Australian Hordeum leporinum biotypes. Pest management science 68, 757763.

Owen, MJ, Martinez, NJ, Powles, SB (2015) Herbicide resistance in Bromus and Hordeum spp. in the Western Australian grain belt. Crop and Pasture Science 66, 466-473.

Recasens, J, García, AL, Cantero-Martínez, C, Torra, J, Royo-Esnal, A (2016) Long-term effect of different tillage systems on the emergence and demography of Bromus diandrus in rainfed cereal fields. Weed research 56, 31-40.

Rumball, PJ (1970) Cost of barley grass. In 'Proceedings of the NZ Weed and Pest Control Conference 23'. (Ed LJ Matthews) pp. 77-82. (The New Zealand Plant Protection Society Inc.: Palmerston North, New Zealand)

Shergill, LS (2016) 'Characterisation and management of herbicide resistance in barley grass (Hordeum glaucum Steud.).' PhD thesis, University of Adelaide, SA.

Shergill, LS, Boutsalis, P, Preston, C, Gill, GS (2016a) Fitness costs associated with 1781 and 2041 ACCasemutant alleles conferring resistance to herbicides in Hordeum glaucum Steud. Crop Protection 87, 6067.

Shergill, LS, Fleet, B, Preston, C, Gill, G (2015a) Incidence of Herbicide Resistance, Seedling Emergence, and Seed Persistence of Smooth Barley (Hordeum glaucum) in South Australia. Weed Technology 29, 782792. 
Shergill, LS, Fleet, B, Preston, C, Gill, G (2016b) Management of ACCase-Inhibiting Herbicide-Resistant Smooth Barley (Hordeum glaucum) in Field Pea with Alternative Herbicides. Weed Technology 30, $441-447$.

Shergill, LS, Malone, J, Boutsalis, P, Preston, C, Gill, G (2015b) Target-Site Point Mutations Conferring Resistance to ACCase-Inhibiting Herbicides in Smooth Barley (Hordeum glaucum) and Hare Barley (Hordeum leporinum). Weed Science 63, 408-415.

Shergill, LS, Malone, J, Boutsalis, P, Preston, C, Gill, G (2017a) Basis of ACCase and ALS inhibitor resistance in Hordeum glaucum Steud. Pest Management Science 73, 1638-1647.

Shugg, AW, Vivian, GW (1973) Barley grass: its effects on the value of sheep products. In 'Proceedings of the NZ Weed and Pest Control Conference 26'. (Ed M Hartley). pp.82-86. (The New Zealand Plant Protection Society Inc.: Auckland, New Zealand)

Sloane, Cook, King, Australian Wool Corporation (1989) The Economic impact of pasture weeds, pests \& diseases on the Australian wool industry : a report. (Australian Wool Corporation: Melbourne)

Smith, C (2014) Quantifying the costs associated with grass seed damage to lamb carcasses, December 2014. Meat and Livestock Australia, North Sydney, NSW.

Smith, D (1968) The growth of barley grass (Hordeum leporinum) in annual pasture. 1. Germination and establishment in comparison with other annual pasture species. Australian Journal of Experimental Agriculture 8, 478-483.

Thomas, B, Matthews, R (2016) Australian Sheep Industry Projections 2017 [Online]. Available at https://www.mla.com.au/globalassets/mla-corporate/prices--markets/documents/trends--analysis/sheepprojections/mla_australian-sheep-industry-projections-2017.pdf (accessed 30 October 2017)

Tozer, K, Marshall, A, Edwards, G (2008) Methods of reducing ripgut brome seed production and carcass damage. In 'Proceedings of the New Zealand Grassland Association Volume 70'. pp. 265-269. (New Zealand Grasslands Association, Blenheim, New Zealand).

Warr, G, New South Wales Department of Agriculture, AWC (1980) Vegetable fault contamination of wool : [final report], Sydney, New South Wales.

\section{Figures}

Fig 1. Significant penetration of the skin by barley grass seeds across the body of a young Merino sheep located in Central West New South Wales (photo courtesy of K. Behrendt). 
Seed contamination in sheep: new investigations

419 Fig.2. Distribution and total density of sheep carcasses showing seed contamination during years 2009 to 2015.

420 Darker discolouration indicates higher density of contamination.

421

422

423

424

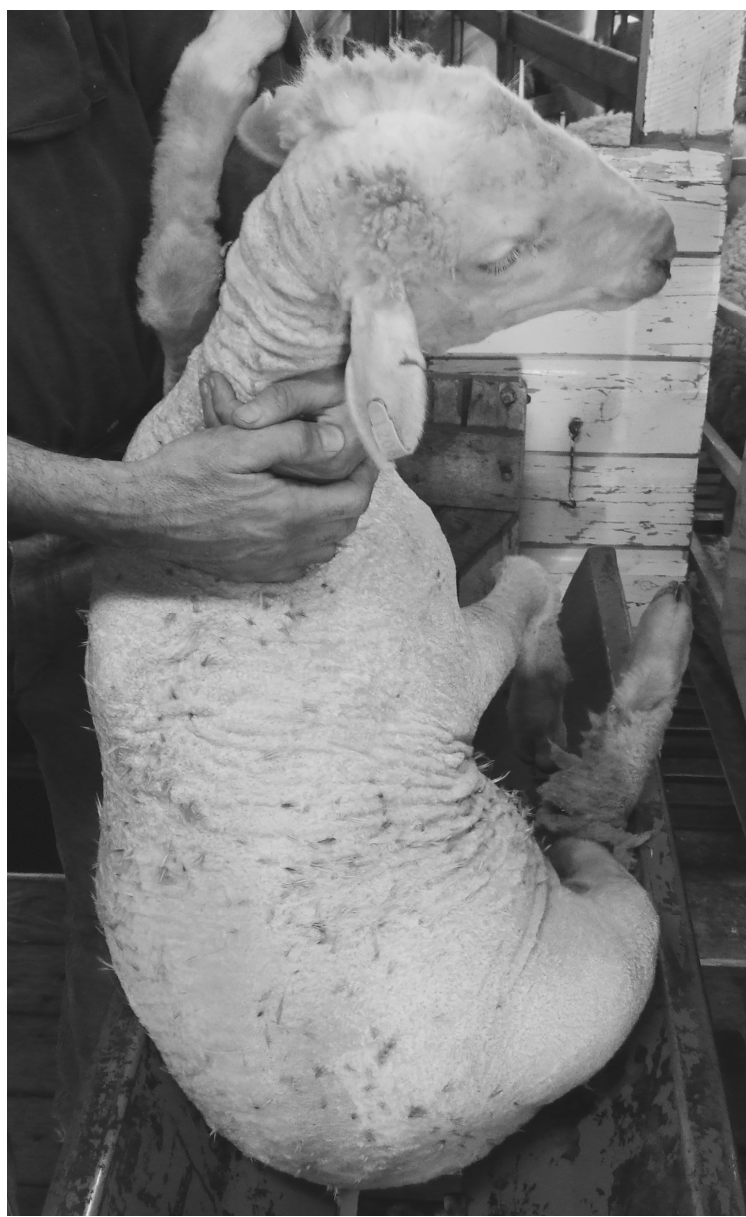

Fig 1. Significant penetration of the skin by barley grass seeds across the body of a young Merino sheep located in Central West New South Wales (photo courtesy of K. Behrendt). 
Seed contamination in sheep: new investigations

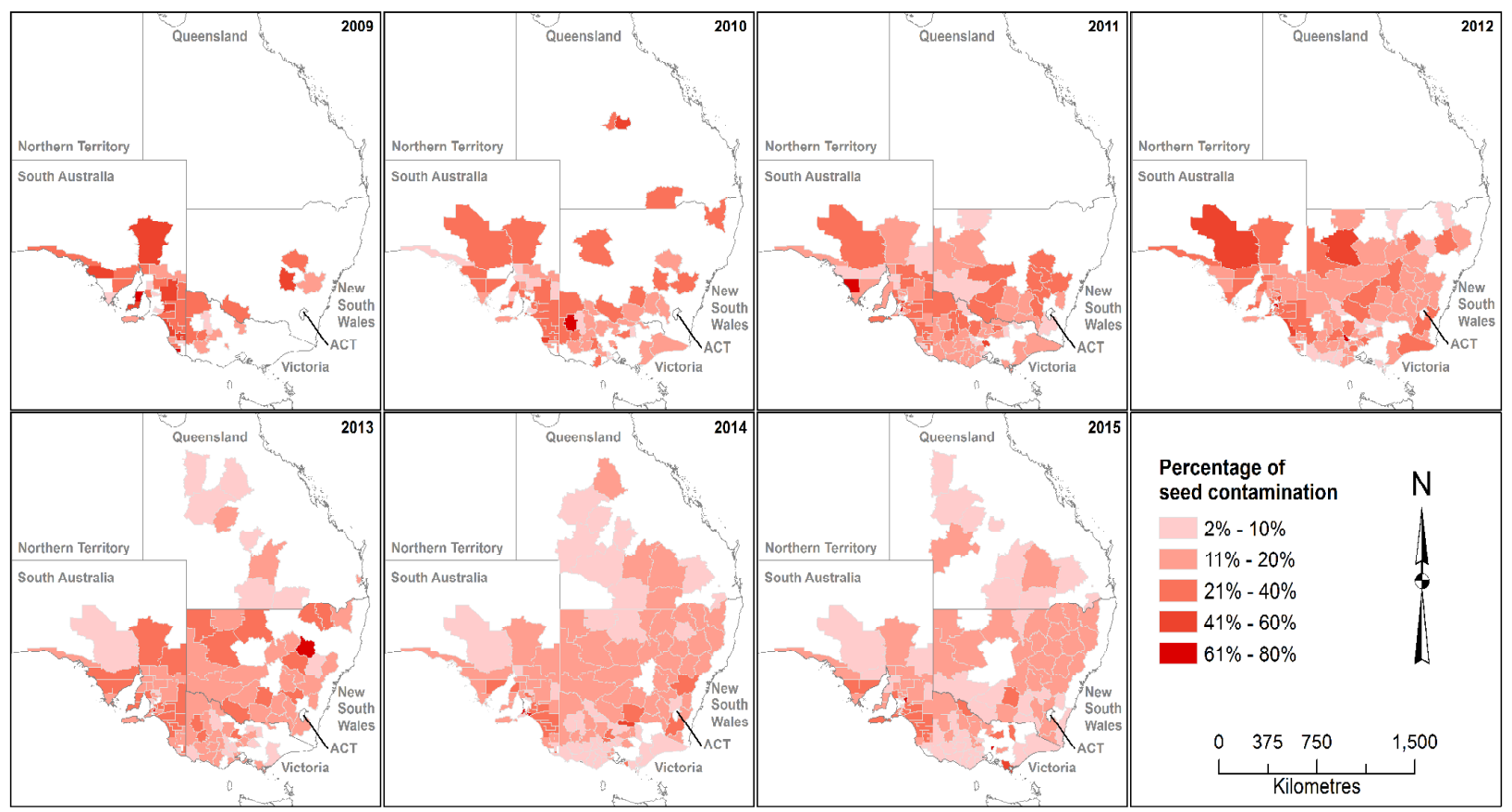

427 Fig.2. Distribution and total density of sheep carcasses showing seed contamination during years 2009 to 2015.

428 Darker discolouration indicates higher density of contamination. 


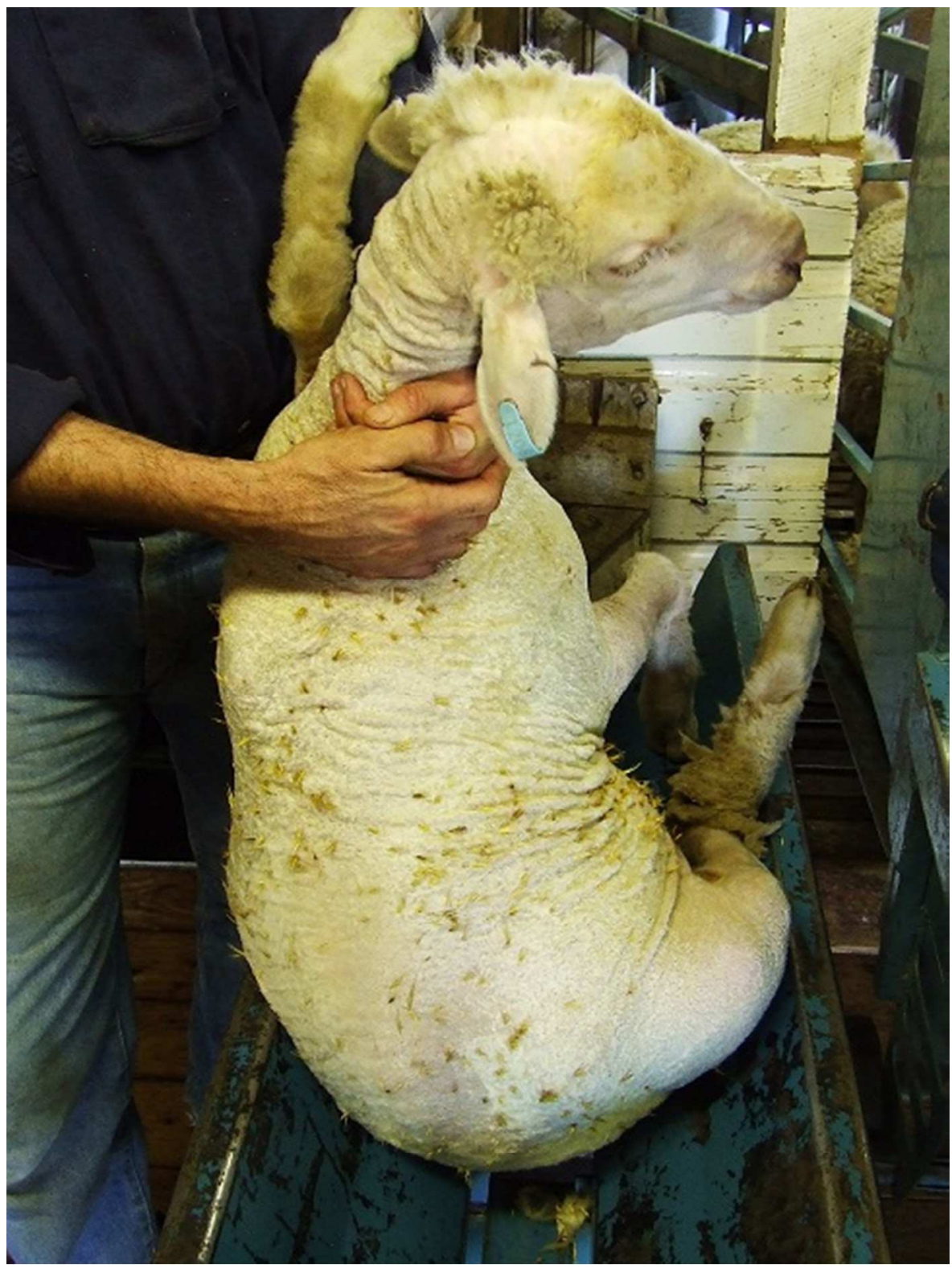

Fig 1. Significant penetration of the skin by barley grass seeds across the body of a young Merino sheep located in Central West New South Wales (photo courtesy of K.Behrendt).

$171 \times 228 \mathrm{~mm}(72 \times 72 \mathrm{DPI})$ 


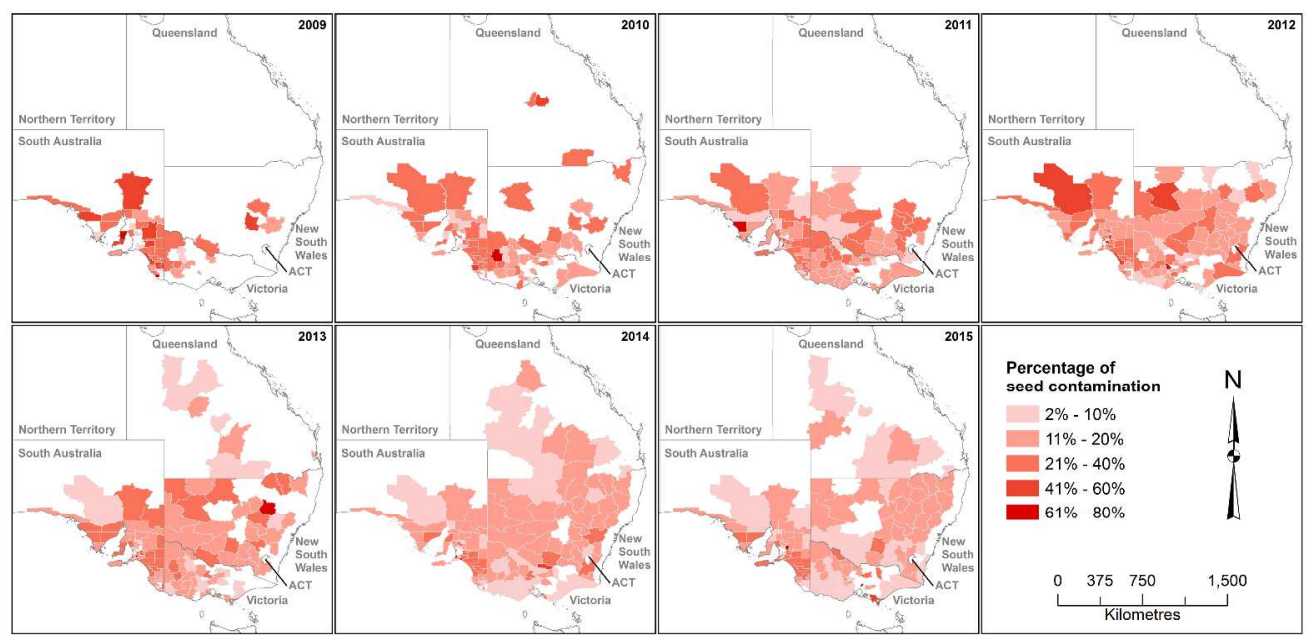

Fig.2. Distribution and total density of sheep carcasses showing seed contamination during years 2009 to 2015. Darker discolouration indicates higher density of contamination. 